\title{
The Relationship between Knowledge of Pregnant Women about Anemia and Prevention of Folic Acid Consumption During Pregnancy
}

\author{
Aryunita \\ Lecturer of Midwifery, Akademi Kebidanan Armina Centre Panyabungan, Indonesia
}

\begin{abstract}
Article Info
ABSTRACT

Article history:

Received December 02, 2022

Revised December 20, 2022

Accepted January 12, 2022

\section{Corresponding Author:}

Arynita

Lecturer of Midwifery,

Akademi Kebidanan Armina

Centre Panyabungan, Indonesia

Email: aryunitaplg@gmail.com

The impact of folic acid deficiency on pregnant women causes birth defects in babies. The purpose of this study was to determine the description of pregnant women's knowledge about the importance of folic acid during pregnancy. This research is descriptive in nature using primary data by distributing questionnaires to each respondent with a total sampling technique of 30 respondents. From the results of this study, it is known that the knowledge of pregnant women about the importance of folic acid in pregnancy, the majority have less knowledge, namely, 15 respondents (50\%), based on age the majority have sufficient knowledge, namely 11 respondents (36.66\%), with an age group of 20-35 years. , based on education the majority have sufficient knowledge, namely 8 respondents $(26.66 \%)$ with high school education. Based on parity, the majority have less knowledge, namely 6 respondents $(20 \%)$ with skundigravida pregnancy, based on occupation, the majority have less knowledge, namely 7 respondents $(23.33 \%)$ with farmer occupations, based on information sources, the majority have less knowledge, namely 8 respondents $(26.66 \%)$ with electronic media. Therefore, it can be concluded that there are still many pregnant women who do not know the importance of folic acid on fetal brain development.
\end{abstract}

\section{Keywords:}

Knowledge, Pregnant Women, Important, Folic Acid

This article is licensed under a Creative Commons AttributionShareAlike 4.0 International License.

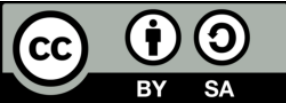

\section{INTRODUCTION}

Folic acid is needed during pregnancy. Folic acid is highly recommended for all women, especially those who are following a pregnancy program. Folic acid plays an important role in the early stages of fetal formation, namely in the formation phase of the central nervous system. Preconceptional folic acid supplementation can reduce the incidence of anemia in pregnancy, reduce the risk for the occurrence of preeclampsia for the mother and reduce the incidence of neural tube defects [1]. The World Health Organization (WHO) states that anemia is a condition in which the number of red blood cells is insufficient to meet the physiological needs of the body. The cause of anemia is generally due to lack of knowledge about anemia, lack of iron, folic acid, Vitamin B12 and Vitamin A. [12].

In ASEAN countries the incidence of anemia varies, in Indonesia around 70\%, in the Philippines around $55 \%$, Thailand $45 \%$, Malaysia 30\%, and Singapore 7\% suffer from anemia. Most anemia in pregnancy is caused by iron deficiency and acute bleeding [12]. The coverage of giving TTD (blood supplement tablets) such as iron, folic acid, protein and vitamins to pregnant women in Indonesia in 2018 was $81.16 \%$. This figure has not reached the 2018 Rensta target of $95 \%$. [3].

Based on the survey, the percentage coverage of pregnant women who received 90 iron or folic acid during pregnancy was $75.85 \%$, an increase compared to $2016(73.31 \%)$, so the coverage of giving iron tablets during pregnancy has not been able to reach the national target set at $80 \%$. [8] 
The incidence of pregnant women in Mandailing Natal consuming folic acid or iron during pregnancy with a percentage of $57.18 \%$, the coverage of giving iron tablets during pregnancy has not been able to reach the target. Based on an initial survey conducted by researchers in January 2021 in Gunung Tua Julu Village, Panyabungan District, Mandailing Natal Regency, that of 30 pregnant women, only 10 knew about the importance of folic acid during pregnancy. Based on the above background, the researchers are interested in conducting research on the relationship between knowledge of pregnant women about anemia and consuming folic acid during pregnancy in Gunung Tua Julu Village, Panyabungan District, Mandailing Natal Regency, January-June 2021.

\section{METHOD}

The type of research used is quantitative with a cross sectional design. This research was conducted in Gunung Tua Village with data collection time starting from January to July 2021. The data collection tool was in the form of a questionnaire. The population in this study were all pregnant women in Gunung Tua Julu Village, Panyabungan District, Mandailing Natal Regency in 2021 as many as 30 people. Total sampling sampling technique with a sample of 30 respondents. Data analysis used univariate analysis and bivariate analysis. Univariate analysis In general, this analysis only produces the distribution of the frequency and percentage of each variable. Bivariate analysis was carried out to see the relationship of each variable using the test chi square statistic with significance level $(a=0,5)$.

\section{RESULTS AND DISCUSSION}

\subsection{Results}

Table 1. Distribution of Respondents Characteristics

\begin{tabular}{l|r|r}
\hline \multicolumn{1}{c|}{$\begin{array}{c}\text { Characteristics of } \\
\text { respondents }\end{array}$} & Frequency & Percentage \\
\hline Age & 3 & 10 \\
\hline $17-19$ & 24 & 80 \\
\hline $20-35$ & 3 & 10 \\
\hline $36-40$ & & 16,6 \\
\hline Education & 5 & 23,33 \\
\hline Primary school & 7 & 46,66 \\
\hline Junior High School & 14 & 13,33 \\
\hline Senior High School & 4 & \\
\hline Limited company & & 36,66 \\
\hline Profession & 11 & 26,66 \\
\hline Farmer & 8 & 26,66 \\
\hline Housewife & 8 & 10,00 \\
\hline Entrepreneur & 3 & \\
\hline civil Servant & &
\end{tabular}

Based on table 1 shows the majority age 20-35 years 42 respondents (80\%) and a minority aged 36-40 years 3 respondents (10\%). Based on the work of the majority as farmers / gardeners 11 respondents (36.66\%) and the minority as ASN 3 respondents (10.00\%). Based on the education level of the majority SMA 14 respondents $(46.66 \%)$ and the minority $\mathrm{S} 14$ respondents $(13.33 \%)$

Table 2. Respondents Knowledge Level About Folic Acid

\begin{tabular}{c|l|r|r}
\hline No & Knowledge & Frequency $(\mathrm{F})$ & \multicolumn{1}{|c}{ Percentage (\%) } \\
\hline 1. & Well & 3 & 10 \\
\hline 2. & Enough & 12 & 40 \\
\hline 3. & Not enough & 15 & 50 \\
\hline \multicolumn{2}{r}{ Total } & 30 & $100 \%$ \\
\hline
\end{tabular}

Based on the table above, it can be seen that the majority of respondents have less knowledge, as many as 15 respondents (50\%), while the minority of respondents have good knowledge as many as 3 respondents $(10 \%)$.

Table 3. Distribution of Respondents' Actions Consuming Folic Acid during pregnancy

\begin{tabular}{l|l|r|r}
\hline No & Action & Frequency $(\mathrm{F})$ & Percentage $(\%)$ \\
\hline 1 & Consuming & 13 & 43,33 \\
\hline 2 & Not consuming & 17 & 56,67 \\
\hline & Total & 30 & 100 \\
\hline
\end{tabular}

Based on table 3 above, the majority of respondents consuming folic acid did not consume 17 respondents (43.33\%) and the minority consumed 13 respondents $(43.33 \%)$. 


\subsection{Discussion \\ 3.2.1. Characteristics of Respondents \\ 1) Respondent's Age}

From the results of research conducted on 30 respondents, it was found that the majority of respondents' ages were in the age interval of 20-34 years, namely 24 respondents (80\%). Age is an index that places individuals in the order of development, age affects a person's level of knowledge where the older a person is, the more knowledge is obtained[16].

\section{2) Respondent's Education Level}

From the results of the research, it can be seen that of the 30 respondents studied, the majority have high school education, namely 14 respondents $(46.66 \%)$ and the minority have tertiary education, namely 4 respondents (13.33\%). According to research conducted by Yunelda Puspita (2015), the majority of the 22 respondents had high school education who had less knowledge as many as 4 respondents $(50 \%)$, and the minority had good college education, as many as 2 respondents (100\%). According to Notoatmodjo (2017), education has the most important role in determining the quality of human beings, with human education it is considered to gain knowledge, the higher the quality of human life education will be. This study shows that the majority of respondents have a high school education. The level of education indirectly affects a person's knowledge. Low education has the possibility of stunted fetal growth due to lack of information or knowledge that leads to unhealthy behaviors and lifestyles such as not knowing about the importance of folate asthma during pregnancy to fetal growth, as well as preventing anemia in pregnancy.

\section{3) Respondent's Employment Level}

From the results of the study, it can be seen that of the 30 respondents, the majority have less knowledge, as many as 7 respondents $(23.33 \%)$ with jobs as farmers, and each minority with good and sufficient knowledge, namely 1 respondent $(3.33 \%)$ with self-employed jobs and civil servants. Work is an activity what people must do to meet their daily needs, humans have basic needs that must be met [18]. Work affects a person's physical activity. People who do not work activities are not much Everyone experiences stress related to their work. This can be influenced because their work in the fields works from morning to evening. Farmers work hard every day. A job that takes a long time. Meanwhile, farmers sometimes have a low economic status that triggers anemia

\subsubsection{Anemia Prevention Measures}

From the results of the study, the majority of respondents' actions in preventing anemia were in the category of not consuming folic acid, as many as 17 respondents (56.67\%) and the minority category consuming folic acid as many as 13 respondents (43.33\%). Action is an attitude that tends to act (practice). Attitudes are not necessarily manifested in actions, because for the realization of actions other factors are needed, including the existence of facilities and infrastructure [16]. According to Noorkasiani [18] actions are caused by several factors such as: predisposition, namely attitudes, beliefs, values, motivation and knowledge. An attitude is not necessarily automatically manifested in an action. To realize an attitude into a real action, a supporting factor or an enabling condition is needed, including facilities and infrastructure. Personal experience must give a strong impression to be the basis for forming attitudes. Attitudes and knowledge can influence people's actions [19].

\subsubsection{The Relationship of Knowledge About Anemia With Folic Acid Consumption}

Based on the research that researchers did to determine the relationship between knowledge about anemia and someone's actions, where the majority of respondents suffer from anemia have a low level of knowledge about folic acid consumption during pregnancy both its definition, causes, signs and symptoms and prevention. So that this affects the respondent's actions in taking preventive actions.

\section{CONCLUSION}

From the results of research regarding the relationship between knowledge of pregnant women about anemia and prevention of folic acid consumption during pregnancy in Gunung Tua Julu Village, Panyabungan District, Mandailing Natal Regency, January-June 2021, the following conclusions can be drawn: Based on the results of research conducted, it is known that from 30 The majority of respondents who are pregnant women who have less knowledge are as many as 15 respondents. Based on age, it can be seen that of the 30 respondents, the majority have sufficient knowledge, as many as 11 respondents. With the age group of 20-35 years.

From the results of research regarding the relationship between knowledge of pregnant women about anemia and prevention of folic acid consumption during pregnancy in Gunung Tua Julu Village, Panyabungan District, Mandailing Natal Regency, January-June 2021, the following conclusions can be drawn: Based on the results of research conducted, it is known that from 30 The majority of respondents who are pregnant women who have less knowledge are as many as 15 respondents. Based on age, it can be seen that of the 30 respondents, the majority have sufficient knowledge, as many as 11 respondents. With the age group of 20-35 years. Based on education, it can be seen that of the 30 respondents, the majority have sufficient knowledge, namely 8 respondents with high school 
education. Based on parity, it can be seen that the majority of the 30 respondents have less knowledge, namely respondents. With a SC undigravida pregnancy. Based on the work, it can be seen that of the 30 respondents, the majority are knowledgeable, 7 respondents.

\section{ACKNOWLEDGEMENTS}

Author thanksall parties involved make it a success. In most cases, sponsor and financial support acknowledgments.

\section{REFERENCES}

[1] ACOG,2016. Peran Asam Folat,https://www.researchgate.net/publication/326961115

[2] Ariani, 2012. Defenisi Paritas, http:digilib.uns.ac.id

[3] Arikunto, 2010. Aspek Pengukuran, http://ethess.uin-malang.ac.id dr. Senoaji. P, 2012. Seputar Kehamilan.

[4] Goetzl, 2017. Asam folat, https://www.researchgate.net/publication/326961115.

[5] Hardiansyah, 2016. Defenisi Kehamilan, http://eprints.ums.ac.id/67865/1Jannah, 2012. Pekerjaan,https://dspace.uii.ac.id

[6] Kurniawan, 2017. Pendidikan, http://eprints.ums.ac.id/75947/16/BAB\%20II.pdf.

[7] Lonish, 2014. efek samping asam folat yang harus kita hindari. http://www.babylonish.com_.

[8] Manuaba, 2013. pengertian paritas. http://repository.ump.ac.id/981/3/Eki\%20Yuniarti

[9] Khattak ST, Khan M, Naheed T, Khattak Iu, Ismail M. Prevalence and management of anencephaly at Saidu Teaching Hospital, Swat. J Ayub Med Coll Abbottabad. 2010;22(4):61-63.

[10] Rebecca JS, Daniel JT. Maternal periconceptional folic acid intake and risk of autism spectrum disorder and developmental delay in the CHARGE (childhood Autism Risks from Genetics and Environment) case-control study. Am J Clin Nutr. 2012;96(1):80-89. doi: 10.3945/ajen.110.004416.

[11] Nasir BB, Fentie AM, Adisu MK (2020) Adherence to iron and folic acid supplementation and prevalence of anemia among pregnant women attending antenatal care clinic at Tikur Anbessa Specialized Hospital, Ethiopia. PLoS ONE 15(5): e0232625. https://doi.org/10.1371/journal.pone.0232625.

[12] Organization WH: Medical management of abortion, 2018. In.: World Health Organization; 2018.

[13] Harvey T, Zkik A, Auges M, Clavel T: Assessment of iron deficiency and anemia in pregnant women: an observational French study. Women's Health 2016, 12(1):95-102. pmid:26693881.

[14] Kassa GM, Muche AA, Berhe AK, Fekadu GA: Prevalence and determinants of anemia among pregnant women in Ethiopia; a systematic review and meta-analysis. BMC hematology 2017, 17(1):17.

[15] Begum S: Factors associated with adherence to iron folic acid supplementations during pregnancy in Uttar Pradesh. Indian Journal of Maternal and Child Health 2012, 14(2):8.

[16] Melku M, Addis Z, Alem M, Enawgaw B: Prevalence and predictors of maternal anemia during pregnancy in Gondar, Northwest Ethiopia: an institutional based cross-sectional study. Anemia 2014, 6 .

[17] Rebecca JS, Daniel JT. Maternal periconceptional folic acid intake and risk of autism spectrum disorder and developmental delay in the CHARGE (childhood Autism Risks from Genetics and Environment) case-control study. Am J Clin Nutr. 2012;96(1):80-89. doi: 10.3945/ajcn.110.004416.

[18] Bazzano LA. Folic acid supplementation and cardiovascular disease: the state of art. The Am J Med Sci. 2009;338(1):48-49. doi: 10.1097/MAJ.0b013e3181aaefd6.

[19] Oncel MY, Calisici E, Ozdemir R, Yurttutan S, Erdeve O, Karahan S, et al. Is Folic Acid Supplementation Really Necessary In Preterm Infants With $\leq 32$ Weeks of Gestation? J Pediatr Gastroenterol Nutr. 2013 Sep 18 .

[20] Ministry of Health, Republic of Indonesia. Pedoman Program Pemberian dan Pemantauan Mutu Tablet Tambah Darah Untuk Ibu Hamil. Jakarta: Millenium Challenge Account - Indonesia; 2015. 